\title{
Electronic Payment in Cashless Economy of Nigeria: Problems and Prospect.
}

\author{
Nwankwo, Odi., Ph.D \\ Department of Banking and Finance, Ebonyi State University, P.O.Box, 435 Abakaliki \\ Chartered Institute of Bankers of Nigeria
}

Tel: 80-35-763-229_E-mail: Odinwankwo2002@Yahoo.Com

Eze, Onyekachi Richard

Department of Banking and Finance, Ebonyi State University, P.O.Box 435 Abakalik

Chartered Institute of Bankers of Nigeria

Tel: 80-36-185-506Ｅ-mail: Ezerich2009@Yahoo.Ca

Received: Nov. 8, 2012 Accepted: November 17, 2012 Published: January 1, 2013

doi:10.5296/jmr.v5i1.2650

URL: http://dx.doi.org/10.5296/jmr.v5i1.2650

\begin{abstract}
Before the emergence of modern banking system, banking operation was manually done which lead to a slowdown in settlement of transactions. This manual system involves posting transactions from one ledger to another with human hands. This work examines electronic payment in cashless economy of Nigeria: Problems and Prospect. The new policy by Central Bank of Nigeria $(\mathrm{CBN})$ on cashless system of payment has raised a lot of concern to the growth of Nigerian economy, with the objective of reducing robbery, high cost of processing cash, revenue leakages, inefficient treasury management, promoting economic development through financial intermediation, among others. The aim of this paper is to ascertain the extent to which electronic payment affect cashless economy of Nigeria. Descriptive research design was used to carry out this study. The study indicates that the electronic system of payment has a great implication in cashless economy of Nigerian but it will led to significant decrease in deposit mobilization and credit extension by Nigerian deposit money banks. Consequently, the authors concluded that cashless system of payment will be examined and develop the e-payment system first, so that people will be used to it before talking of cashless economy. This is because; bulk of the Nigerian economy is driven by SME and petty traders. To retain this policy of cashless economy in Nigeria, the authors recommended that the
\end{abstract}


migration of our payments system towards a cashless society would require some reforms and a lot of effort and sensitization especially for low income group, who are currently deeply rooted in using cash and see it as a convenient and easy way of receiving and making payments. The sensitization exercise would require the combined effort of various stakeholders, including government, financial institutions, clergy and non-bank providers of payment services. There should be improvement in infrastructural development so as to enhance e-payment system.

Keywords: Cashless Economy, Electronic Payment, economy, revenue leakages, PoS terminal, robbery. 


\section{Introduction}

Before the emergence of modern banking system, banking operation was manually done which lead to a slowdown in settlement of transactions. This manual system involves posting transactions from one ledger to another with human hands. Figures or counting of money which should be done through computers or electronic machine were computed and counted manually which were not $100 \%$ accurate thereby resulting to human errors. Most banks then used only one computer in carrying out transactions which helped to ameliorate the sluggish nature of banking transaction.

According to David (2012), Nigeria did not embrace electronic banking early when compared to developed countries. Nigeria adopted electronic banking system in the early 2000s. During the introduction of electronic banking system, the use of raw cash was said to have breed corruption through the "cash and carry syndrome" usually linked with the swift movement of Ghana-must go" bags by some politicians. Electronic banking is defined as the use of computers to carry out banking transactions such as withdrawals through cash dispensers or transfer of funds at point of sale. Since electronic banking started in all Nigeria banks, it has been a woe for civil servants; checks show that some staff in establishments such as the national boundary commission for instance, are yet to receive their salaries for the previous months as efforts to electronically transfer salaries into their account have failed (Ibrahim, 2009).

James, (2009) a banker reported to vanguard annual report that "we should not destroy electronic-banking by looking at the negative aspects; we must strive towards perfecting it". He also said that the volume of data generated by the Government ministries, agencies is much, making it a bit difficult for banks to cope. Mathew, (2009) a civil servant says in his report to vanguard annual report on banks and cards that government should have done its homework "very well" before introducing the system, "they plugged us into a system they were not prepared for and the result is untold hardship visited on innocent people”.

The payments system plays a very crucial role in any economy, being the channel through which financial resources flow from one segment of the economy to the other. Therefore, it represents the major foundation of the modern market economy. Essentially, there are three pivotal roles for the payments system namely; the Monetary Policy role, the financial stability role and the overall economic role (CBN, 2011).

During the course of the past ten years the Central Bank of Nigeria (CBN), in collaboration with the Bankers Committee, launched the first major initiative to modernize the payments system. The starting point was to automate the cheque clearing system and make it a veritable platform for development of electronic payment channels. Hitherto cheques processing and computations of the net settlement position of banks were done manually. The implementation of the new procedures and rules based on magnetic ink character recognition (MICR) technology revolutionized the cheque clearing system. Consequently, a Centralized Automated Clearing process was established in Lagos clearing zone, whereby with MICR Reader Sorters, necessary information on cheques are captured, built into clearing files and electronically transmitted to the clearing house, from where the net settlement position of participating banks 
are automatically computed and also electronically transmitted to the Central bank for final settlement. The clearing cycle was subsequently reduced from 5 days to 3 days, which all clearing cheques both local and up-country now takes 3days to clear (CBN, 2011).

The Nigerian cashless system of payment has been evolving in line with the global payments evolution. Cashless system of payments and instruments are significant contributors to the broader effectiveness and stability of the financial system. Innovations in technology and business models have implications for the efficiency and safety of cashless system of payments. Cashless system of payment is defined as a society where transactions is functioning, operated, or performed without using coins or banknotes for money transactions but instead using credit cards or electronic transfer of funds. New technology and new participants in the cashless system payments, for example non-bank providers will support the wider financial inclusion agenda.

The nation's quest of migrating from cash to cashless economy has been on the front burner. Analysts have posited that to meet the target of becoming one of the leading world economies by the year 2020, efforts must be made to embrace electronic payment system in its entirety. It was in this consciousness that the Central Bank of Nigeria (CBN), the apex regulatory body of the banking sector, came up with a reform policy to check the increasing dominance of cash in the banking sector in order to enhance e-payment system in the economic landscape.

By way of a background, the currency in circulation as at the end of August 2011 stood at N1.42 trillion. Also, the currency outside bank vaults stood at N1.025 trillion at the end of February, from N1.033 trillion and N1.082 trillion in January 2011 and December 2010, respectively (CBN, 2011).

Adoption of electronic banking which was supposed to ease banking transactions rather resulted to woes to customer. Most people complain of time wasted in banks. This occurs when there is power failure in banks resulting to slow down in operation. The aim of this paper is to examine electronic payment in cashless economy of Nigeria: Problems and Prospect. Section two provides the review of relevant literatures, section three provides the conclusion and recommendation.

\section{Review of Related Literature}

\subsection{Empirical Review}

In recent years, many authors have in one way or the other investigated the introduction of electronic banking and its implications on the economy in both developed and developing countries. In the works of Taylor and Todd (1995) and Gefen and Straub (1997), it was found that gender has a direct influence on adoption of technology with men and women having different rates of computer technologies adoption. Putrevu (2002) using descriptive survey to ascertain the origin of technology and information difference between man and woman. He found out that difference in information processing exists between men and women and as such both genders will have different rate of technology acceptance. 
Gikandi and Bloor (2009) used time series data to investigate the determinants of the adoption and influence of e-commerce involving 90\% of the retail banks in Kenya. They found out that there was a drastic shift in the importance attached to some e-banking drivers between years 2005 and 2009.

Olatokun and Igbindion (2009) used diffusion of innovation (DOI) theory to investigate the adoption of Automatic Teller Machines in Nigeria. They found out that the constraints Relative Advantage, Complexity, Observeability, Compatibility, and Trialability were positively related to attitude to the use of ATM cards in Nigeria. Olorunsegun (2010) used cluster sampling technique to study the impact of electronic banking in Nigerian banking system. He found out that a bank has an effective electronic banking system which has improved its customer's relationship and satisfaction.

James (2012) used Statistical Package for Social Sciences (SPSS) to investigate the acceptance of E-banking in Nigeria. The result shows that acceptance of e-banking in Nigeria is significantly influenced by Age, Educational Background, Income, Perceived Benefits, Perceived Ease of Use, Perceived Risk and Perceived Enjoyment. Morufu and Taibat (2012) used qualitative survey to ascertain banker's perceptions of electronic banking in Nigeria. The results suggest that bankers in Nigeria perceive electronic banking as a tool for minimizing inconvenience, reducing transaction costs, altering customers queuing pattern and saving customers banking time.

Olajide (2012) used theories to investigate cashless banking in Nigeria and its implications on the economy. He found out that cashless banking will boost the economy on the long run. Zeithaml and Gilly (1987) used technology acceptance theory to determine the Characteristics affecting the acceptance of retailing technologies: a comparison of elderly and non-elderly consumers in developed country. He opined that there is existence of a positive relationship between education, income, and exposure to mass communication and the adoption of Electronic Funds Transfer (EFT) and the relationship was greater for younger than for older consumers.

Lee, Lee, and Schumann (2002) used qualitative survey to ascertain the influence of communication source and mode on consumer adoption of technological innovations in Nigeria. They discovered the older the adopters the lower the rate of technology adoption. Egwali (2008) used consumer acceptance theory to investigate customers perception of security indicators in online banking Sites in Benin, Nigeria. He found out that Security Indicators (SI) are not very effective at alerting and shielding users from revealing sensitive information to fool e-banking sites in Nigeria.

Hogarth, Kolodinsky, and Gabor, (2008) used diffusion innovation theory to investigate the Consumer Payment Choices: Paper, Plastics or Electrons. They found out that increases in income and education also elicit a positive effect on adoption of electronic banking, regardless of the technology. On the other hand, the impacts of other demographic characteristics on adoption are less clear'. 
Karjaluoto, Mattila and Pento (2002) used consumer acceptance theory to determine online banking acceptance. They found out that attitude towards online banking and its usage is significantly affected by Prior Computer Experience, Prior Technological Experience, Personal Banking Experience and Reference Group Influence. Rotchanakitumnuai and Speece (2004) on the other hand found out that Web Benefits (Information Quality, Information Accessibility, Information Sharing, and Transaction Benefit) and Web Barriers (Organisation Barrier, Trust, and Legal Support) are key factors influencing e-banking adoption by customers.

Ezeoha (2006) used descriptive survey to examine regulating internet banking in Nigeria, problem and challenges. He found out that Internet banking in Nigeria is slowly been embraced by customers because Internet practice in Nigeria has been abused by cyber fraudsters who use real and deceptive banking websites to fool users' and set their sensitive information and funds. Pikkarainen, Pikkarainen, Karjaluoto and Pahnila (2004) used Technology Acceptance Model to investigate Consumer Acceptance of Online Banking. They found out that perceived usefulness and perceived ease of use of online banking among other factors significantly affects the use of e-banking; other factors according to them are Perceived Enjoyment, Information on Online Banking, Security and Privacy, Quality of Internet Connection.

Lasser, Manolis and Lassar (2005) used qualitative survey to investigate into factors influencing the use of e-banking in European countries. They discovered that consumer innovativeness and personal characteristics are the key determinants of online banking adoption Security issues top the list of factors limiting the acceptance of e-banking services by customers.

\subsection{Theoretical Framework}

Based on the empirical literature, the theoretical framework of this study is Technology Acceptance Model and Diffusion of Innovation (DOI) Theory. Technology Acceptance Model (TAM) is an information systems theory that models how users come to accept and use a technology that will encourage economic growth. The model suggests that when users are presented with a new technology, a number of factors influence their decision about how and when they will use it, notably: Perceived usefulness (PU) - This was defined by Fred Davis (1989) as "the degree to which a person believes that using a particular system would enhance his or her job performance". And Perceived ease-of-use (PEOU) - Davis defined this as "the degree to which a person believes that using a particular system would be free from effort. This model was developed by Fred Davis (1989) and used by Pikkarainen, Pikkarainen, Karjaluoto and Pahnila (2004). While Diffusion of Innovations theory is a theory that seeks to explain how, why, and at what rate new ideas and technology spread through cultures. This theory was developed by Gabriel Trade (1890) and Everett_Rogers, a professor of rural sociology, popularized the theory in his 1962 book Diffusion of Innovations. He said diffusion is the process by which an innovation is communicated through certain channels over time among the members of a social system. This theory was used by Hogarth, Kolodinsky and Gabor (2008) among others. The implication of these two theories is that the earlier people of this 
country accept cashless economy, the earlier it improves business activities and in turn encourage economic growth in the Nigeria.

\subsection{Concept of Cashless Economy}

The internet is perhaps one of the most useful tools to businesses and individuals in contemporary world economies. Its use has touched virtually every aspect of human endeavour especially banking. Technological breakthroughs and product designs have led to the emergence of e-banking services which, in recent time has become globally popular except in developing countries including Nigeria (James, 2012).

The Central Bank of Nigeria (CBN) in 2011 released a circular on the introduction of 'cashless' policy which sets cash deposit and withdrawal limits. That the country would from June $1^{\text {st }}$ 2012 join the committee of nations that embrace the electronic means of payment and limit the use of cash to the very barest. The apex bank has also gone ahead to assert that the commencement of its "cashless policy” for cities such as Lagos, Abuja and Port Harcourt to demonstrate the CBN's seriousness about the policy which has generated huge debate from Nigerians. While the apex bank is of the view that the cashless policy is the way to go in line with global trends, many Nigerians both informed and uninformed have divergent views about the policy (CBN, 2011). The Governor of the central bank of Nigeria (CBN), is of the view that the electronic means of payment is the vogue throughout the world. He stressed that the policy, if allowed to succeed, would save the country huge resources such as cost of printing cash and its transportation from the mint to the length and breadth of the country. That such fund could be diverted to other pressing national needs because the use of cash is attributed to corruption problem in Nigeria (Sanusi, 2011).

To show that CBN means business about the policy, it has gone ahead to license six Payment Terminal Service Providers (PTSPs) to support and maintain Point-of-Sale (POS) terminals. This step is a bold demonstration that the apex bank is determined to see this policy work. The bank has kick started the policy in Lagos early 2012. The licensed PTSPs are ITEX, ValueCard, ETOP, Paymaster, Citi Serve and Easy Fuel, which is focused on the downstream sector. CBN also moved a step further by assuring Lagos residents that there would be no need for a separate POS terminal for each type of card scheme, as all terminals would be equipped to accept payments for any type of card. The cards in the scheme are; Verve, Genesis, Master Card, Visa, etc (CBN, 2012). The success of this policy requires the increased use of alternative payment systems including e-banking. Electronic banking is defined as the provision of banking services to customers through the internet (Daniel, 1999). Services offered by banks using the internet include: Mobile banking (M-banking), video banking, fund transfers, e-payments and ATM cards. Of these entire e-banking services banks offer, ATM is by far the most popular in Nigeria. However, technological advancement keeps broadening the frontier of possibilities in all human endeavours and thus more e-banking services are being developed and introduced. As at today, all the deposit money banks in Nigeria offer e-banking services.

Electronic banking and the introduction of the cashless economy is one that has been discussed in literature as found in the Wicksell's, (1935) pure credit economy where, monetary policy without money" (Boianovsky and Trautwein, 2004 in Olajide, 2012). These 
studies considered the case of the cashless economy and the connection between the flows of investor demand as measured by movements in the demand deposits and the real sector and this is further witnessed in Berg, Hann and Strum (2006) who suggest that money does not really matter in the determination of price movements in any economy, hence inflation and that economy can grow without cash as the money base is not relevant for manipulations in the price level while the quantity theorists claim otherwise.

Apart from the monetary policy implications of the introduction of a cashless economy, some authors have investigated the introduction of electronic banking and cashless economy with a look to ascertaining its implications for transactions, regulations, costs to banking and non-bank public (Godschalk and Krueger, 2000; Palley, 2001; Rogers, 2004). However most of these studies were centered on the comparatively more advanced countries of the world which were the likely candidates for the so called e-revolution given the standard of living, the peculiarity of their monetary policy issues and the technological sophistication. With the development of sophisticated forms of money also develops sophisticated forms of financial crimes both at the public and private sectors (Woda, 2006; National Drug intelligence centre, 2008; financial action task force, 2010).

Literature on e-banking and cashless system of banking is one that is quite scanty in less developed countries like Nigeria and this may not be unconnected to the heavy presence of the informal sector in most dual developing economies and the poor banking culture in the same. Hence, against this backdrop there is the need to investigate the problems and prospects of electronic payment in cashless economy of Nigeria.

\subsection{Overview of the Payment Systems in Nigeria.}

There is no law that explicitly and exclusively deals with Payment systems in Nigeria. Rather, the CBN Act, as amended in 1999 gives the Bank the implicit powers to oversee and regulate the payments system. Section 41 of the CBN Act provides that "it shall be the duty of the CBN to facilitate the clearing of cheques and credit instruments for banks carrying on business in Nigeria and for this purpose, the bank shall at any appropriate time and in conjunction with other banks establish clearing houses in premises provided by the Bank in such places as the Bank may consider necessary". Section 17 provides that "the Bank shall have the sole right of issuing currency notes and coins throughout Nigeria". Also, the Nigeria Deposit Insurance Corporation (NDIC) in exercising its' responsibilities as provided by NDIC Act of 1988 as amended in 2006 complements the supervisory function of the CBN in the nation's payment system. The extent of this responsibility is the insuring of all deposit liabilities of banks with exception in order to protect depositors against bank failure and install public confidence in the system. Also the Nigerian Stock Exchange plays a dominant role in the Nigerian Payments and Settlement landscape as the trading in equities is conducted via the floor of the exchange based on encompassing laws and regulations (CBN, 2011).

\subsection{Institutional and Organizational Framework.}

The CBN is the main institution that regulates the payments system in Nigeria. Banks, discount houses, Nigeria Inter-Bank Settlement System (NIBSS), Nigeria Stock Exchange card and 
switching companies remain the key players in the Nigerian payments system. The CBN, complemented by Nigerian Deposit Insurance Corporation (NDIC) provide the necessary oversight function to ensure the efficiency and effectiveness of the payments system in Nigeria. There are over 1000 registered institutions that provide payments/financial services in Nigeria. They include 24 consolidated deposit money banks (as at 31st December, 2011) with many branches, 5 discount houses, 759 micro finance banks, 293 bureau- de- change, 111 finance companies, 90 primary mortgage institutions and 6 development finance institutions (CBN, 2012).

\subsection{Cashless System of Payment and Nigeria Economy}

If the CBN cashless policy is a thing that will lead the country to modern economy, then it is a welcomed idea. But it is an idea of the future, not now. This is because the larger number of participants at the lowest strata of the economy is of such a larger quantum of the Nigerian economy. But they utilise averagely trading capital of so low cash of the thousand naira (N5, 000). Therefore, making them cashless would be a costly burden for the banking industry to administer and also burden in the economy. It would take a lot of effort to steer the country on the path to a cashless economy because millions of people out there are yet to cultivate the banking habit. Nigeria with a population of about 130 million bankable adults has less than 50 million persons with bank accounts (Nweze, 2012). Besides, banks are driving customers away with automated teller machine (ATM)-related fraud, exploitative charges and bad policies. The country cannot have a cashless economy if so many people have no access to banking services. The irony is the ATM, which is the plank upon which this so-called cashless policy stands, is not popular with the Nigerian banking public as many have dumped their ATM cards, some on the advice of their close friends working in the banks where they operate accounts.

\subsection{Problems of Cashless System of Payment in Nigeria.}

According to experts, there are many challenges facing the introduction of cashless system of payment in Nigerian economy. They are as follows:

1. Network Reliability: Instability of Point of Sale (PoS) networks, which is prevalent across all operators, would pose a problem/serve, as a barrier to usage especially when money sent is not received when needed - which is crucial.

2. Fraud: A prevalent fraudulent act among ATM scammers is likely to occur on the point of sale channel.

3. Security: Concerns were also raised about trust in the Agents providing cash-in and cash-out services, this could be risky for customers and the agents if there is no form of security.

4. Charges: How will charges be determined? 
- Location: charges should be based on distance to the sender.

- Amount: the larger the amount, the higher the charge.

- Monthly charges/ access fees.

5. System Stability: Fear of the unknown - the current banking crisis (both deposit money banks and microfinance banks) has not helped in allaying the public's fear.

6. Literacy Issues: This is a situation where not all targeted populace were literate, while some of them do not know how to make use of the e-banking. For instance, a dubious businessman may see a customer that do not know how to operate the PoS terminal and decided to deduct more than what the person consume.

7. Network Operator Provider: Most people were curious to know if this will be done by an existing or a new Point of Sale (POS) service provider. Some people were concerned about usage in rural areas, especially where there is currently no network coverage in terms of money transfer.

8. Inadequate Infrastructural Development: Lack of infrastructural development particularly energy (power) puts a lot of constraints to the operations of e-payment machines.

9. Social and Security threat: Nigerian have been faced with social and security problems since 2011 with the advent of the present regime. The amount of insecurity in the banks and other financial institutions may jeopardize the e-payment programme in Nigeria.

\subsection{Prospects of Cashless Economy}

A variety of benefits are expected to be derived by various stakeholders from an increased utilization of e-payment systems in any country. These include:

- For Consumers: Increased convenience; more service options; reduced risk of cash-related crimes; cheaper access to (out-of-branch) banking services and access to credit.

- $\quad$ For Corporations: Faster access to capital; reduced revenue leakage; and reduced cash handling costs.

- $\quad$ For Government: Increased tax collections; greater financial inclusion; increased economic development. Increased tax collections; greater financial inclusion; increased economic development.

\section{Conclusion and Recommendations}

\subsection{Conclusion}

Nigerian cashless policy has placed much emphasis on high cost of processing cash, robbery among others. One cannot fault the right of the CBN to regulate monetary transaction in the country, which goes a long way in the management of the nation's economy. But this policy was planned without taking into consideration the present state of e-banking in the country. Migration from cash transaction to cashless transaction is not something that should be done in a hurry. We should talk of issue that is practical and realistic in Nigeria. What we should talk about is raising confidence and stably in the banking industry. That is what the CBN should 


\section{Macrothink

first of all address. we believe the velocity is too high. Let's examine and develop the e-payment system first so that people will be used to it before talking of cashless transaction. The bulk of the Nigerian economy is driven by SME and petty traders. With negligible internet penetration in the rural areas, no meaningful electronic security and epileptic power supply what infrastructure does the CBN hopes to build this cashless economy on? Despite the challenges and issues raised, e-payment would gradually penetrate in the economy and reduce the cash and carry syndrome that is in vogue

\subsection{Recommendations}

The following recommendations should be used in achieving, the dreams of e-payment in cashless system in Nigeria.

1. The migration of our payments system towards a cashless society would require some reform and a lot of effort and sensitization especially for low income customers, who are currently deeply rooted in using cash and see it as a convenient and easy way of receiving and making payments. The sensitization exercise would require the combined effort of various stakeholders, including government, financial institutions and non-bank providers of payment services.

2. The cashless system of payments idea was well received by the majority of Nigerians, but with some concerns/challenges which can hamper its success and must be addressed by providers.

3. There is a need for the regulatory authorities to ensure that the policy was properly enforced, through the use of moral suasion to drive it home. Coercive measure should be out of it. On the long run, the economy will be better for it.

4. The transformation from a cash-centric economy to a plastic one would need more than one year, this is because the introduction should be gradual with the fundamental structures; first put into place.

5. Regulatory authorities should ensure that all service providers who have been licensed should start operations because the number of Point of Sale (PoS) terminals in the country is very few. Penalties should be imposed on those providers who have failed to go into the market.

6. Hence before cashless system of payment can be widely accepted and used, consumers must trust and have full confidence in the system, which entails:

- Clear and practical communication.

- High level of security in the system - difficult for scammers/fraudsters.

- Simple and easy processes especially for low income customers.

- Accessible for all.

- Minimal charges. 


\section{References}

Berg, H., Hann, J. and Strum, J. (2006). Does money matter in the ECB strategy? Working paper.

Boianovsky, M. and Trautwein, H. (2004). Wicksell after Woodford. Paper presented at the History of Economics Society meeting at Toronto in June.

CBN, (201) Questions and answers on the CBN policy on cash withdrawal /lodgment limit. Sourced from; http://www.cenbank.org

CBN, (2011). Understanding the Cashless Economy. Extract on 11th June 2012, http://www.cenbank.org/cashless/

CBN, (2012). Guideline on point of sale (POS) and acceptance services in Nigeria.

CBN. (2011). Further Clarification on Lagos Cashless Project, Central Bank of Nigeria, Extract on 11th June 2012, http://www.cenbank.org/cashless/

Daniel, E. (1999). Provision of Electronic Banking in the UK and the Republic of Ireland. $\begin{array}{llll}\text { International Journal of Bank } & \text { Marketing, }\end{array}$ http://dx.doi.org/10.1108/02652329910258934

David, M. (2012). Cashless Economy; Adequate preparation is essential. Newswacth Magazine, Pg. 27

David, S. N. (2012). Can CBN achieve cashless banking system of payment in nigeria. Daily Sun newspaper, pg.26.

Davis, F. D. (1989). Perceived usefulness, perceived ease of use, and user acceptance of information technology. MIS Quarterly, 13(3), 319-340. http://dx.doi.org/10.2307/249008

Egwali, A. O. (2009). 'Customers Perception of Security Indicators in Online Banking Sites in Nigeria' Journal of Internet Banking and Commerce, 14(1), 5-8. Extracted on $12^{\text {th }}$ June, 2012.http://www.arraydev.com/commerce/jibc.

Ezeoha, A. E. (2006). Regulating Internet Banking in Nigeria, Problem and Challenges-Part 2. Journal of Internet Banking and Commerce, 11(1).

Financial Action Task Force. (2010). Money laundering using new payments methods. Sourced from: www.fatf-gafi.org/dataoecd/4/56/46705859.pdf

Gefen, D., \& Straub, D. W. (1997). Gender differences in the perception and use of e-mail: an extension to the Technology Acceptance Model. MIS Quarterly, 389-399. http://dx.doi.org/10.2307/249720

Godschalk, D., \& Krueger, S. (2000). Why e-money still fails; chances of e-money within a competitive payment instrument market. Paper presented for the third Berlin internet economics workshop, Berlin. 
Hogarth, J. M., Kolodinsky, J., \& Gabor, T. (2008). 'Consumer Payment Choices: Paper, Plastics or Electrons. International Journal of Electronic Banking, 1(1), 16-16. http://dx.doi.org/10.1504/IJEBANK.2008.020437

Ibrahim, D. (2009). Boosting payment solution with Visa Card. Daily Champion, pg. 12

James, A. O. (2009). E-Payment and its challenges. Daily Champion, pg.13

James, A. O. (2012). The Acceptance of E-banking by Customers in Nigeria. World Review of Business Research, 2(2), 6-8.

Karjaluoto, H., Mattila, M., \& Pento, T. (2002). Factors Underlying Attitude Formation towards Online Banking in Finland. The International Journal of Bank Marketing, 20(6), 261-272. http://dx.doi.org/10.1108/02652320210446724

Lassar, W. M., Manolis, C., \& Lassar S. S. (2005). The Relationship between Consumer Innovativeness, Personal Characteristics, and Online Banking Adoption. International Journal of Bank Marketing, 23(2), 176-199. http://dx.doi.org/10.1108/02652320510584403

Lee, E., Lee, J., \& Schumann, D. (2002). The influence of communication source and mode on consumer adoption of technological innovations. Journal of Consumer Affairs, 36(1), 1-28. http://dx.doi.org/10.1111/j.1745-6606.2002.tb00418.x

Mary, P., Samson. A. A., \& Akpeti. O. E. (2012). Capital market as a veritable source of development in Nigeria economy. Journal of Accounting and Taxation, 4(1), 7-18. Available online at http://www.academicjournals.org/JAT

Mathew, A. (2009). An empirical investigation of the level of user's acceptance of e-banking in Nigeria based on technology acceptance model. Proceedings of first international conference on mobile e-service, LUATECH, Ogbomosho Nigeria.

Morufu, O., \& Taibat, A. (2012). Bankers perceptions of electronic banking in nigeria: A review of post consolidation experience. Research Journal of Finance and Accounting, 3(2), 5-6.

National Drug intelligence centre, (2008). Money laundering in digital currencies. U.S Department of Justice.

Obodo, E. (2012). What Nigerians think of the cash-less economy policy, pp 1-4.

Olajide, V. C. (2012). Cashless banking in Nigeria and its implications, 1-8. Retrieved online on $23 / 06 / 2012$.

Olatokun, W. M., \& Igbinedion, L. J. (2009). The Adoption of Automatic Teller Machines in Nigeria: An Application of the Theory of Diffusion of Innovation. Issues in Informing Science and Information Technology, 6(2), 373-393.

Olorunsegun, S. (2010). The impact of Electronic Banking in Nigeria Banking System. MBA Research Project Submitted to the Department of Management Science, Faculty of 


\section{Macrothink

Engineering and Technology, Ladoke Akintola University of Technology, Ogbomoso, Oyo State Nigeria. Pp 23-29. Unpublished. Retrieved online on 20/06/2012

Palley, N. (2001). The e-money revolution; challenges and implications for monetary policy. Sourced from: http://www.thomaspalley.com.

Pikkarainen, T., Pikkarainen, K., Karjaluoto, H. and Pahnila (2004). Consumer Acceptance of Online Banking: an Extension of the Technology Acceptance Model. Internet Research, 14(3), 224-235. http://dx.doi.org/10.1108/10662240410542652

Putrevu, S. (2002). Exploring the origins and information processing differences between men and women: implications for advertisers. Academy of Marketing Science Review, 6(1), 23-25. Extracted on $12^{\text {th }}$ June, 2012. www.amsreview.org/

Rogers, E. (2004). Doing without money; a critical assessment of Woodford"s analysis. Working paper sourced from www.economics.adelaide.edu.au/research/papers/doc.

Rogers, E. M. (1983). Diffusion of Innovations. New York: Free Press.

Rotchanakitumnuai, S., \& Speece, M. (2004). Corporate Customer Perspectives on Business Value of Thai Internet Banking. Journal of Electronic Commerce Research, 5(4), 270-286.

Sanusi, L. S. (2011). Cashless economy in Nigeria. International Journal of Finance, 34(2), 18-39.

Taylor, S., \& Todd, P. (1995). Assessing IT usage: the role of prior experience. MIS Quarterly, 561-568. http://dx.doi.org/10.2307/249633

Wicksell, K. (1935). Interest and Prices, (tr.Richard Kahn, London, Macmillan, for the Royal Economic Society).

Woda, S. (2006). Money laundering techniques with electronic payments systems. Information and security journal, 18(2), 27-47.

Zeithaml, V. A., \& Gilly, M. C. (1987). Characteristics affecting the acceptance of retailing technologies: a comparison of elderly and non-elderly consumers. Journal of Retailing, 63(1), 49-68. 